\title{
A Study Of Health Conditions Of Women Working At Karachi Fisheries
}

\author{
Seema Manzoor \\ Asma Manzoor \\ Dua-e-Rehma \\ Women's Studies \\ University of Karachi \\ \& \\ Samina Saeed \\ Department of Political Science \\ University of Karachi
}

\begin{abstract}
This study aims to establish the understanding about the health conditions of women working at Karachi fisheries. The study has also tried to analyze the issues which affect the life of women working at fisheries in their working hours, within the family, while communicating with people around them and in their social life. By using quantitative research method researcher has analyzed different factors and circumstances which these women are experiencing, and the universe of population for this study is chosen as private fisheries near Fish Harbour, West Wharf, Karachi, Sindh, Pakistan. Whereas, convenience and purposive sampling techniques of non-probability sampling method are used in order to collect the data by hundred respondents from various private fishing companies at Karachi fisheries. In Pakistan now more women are connected to labour force due to increased employment opportunities, on the other hand women are doing work outside their homes to gain their economic independence and the rights and social standing like men in the family and society.
\end{abstract}

Key Words: Health, Fisheries, Health Conditions, Physical and Mental Health.

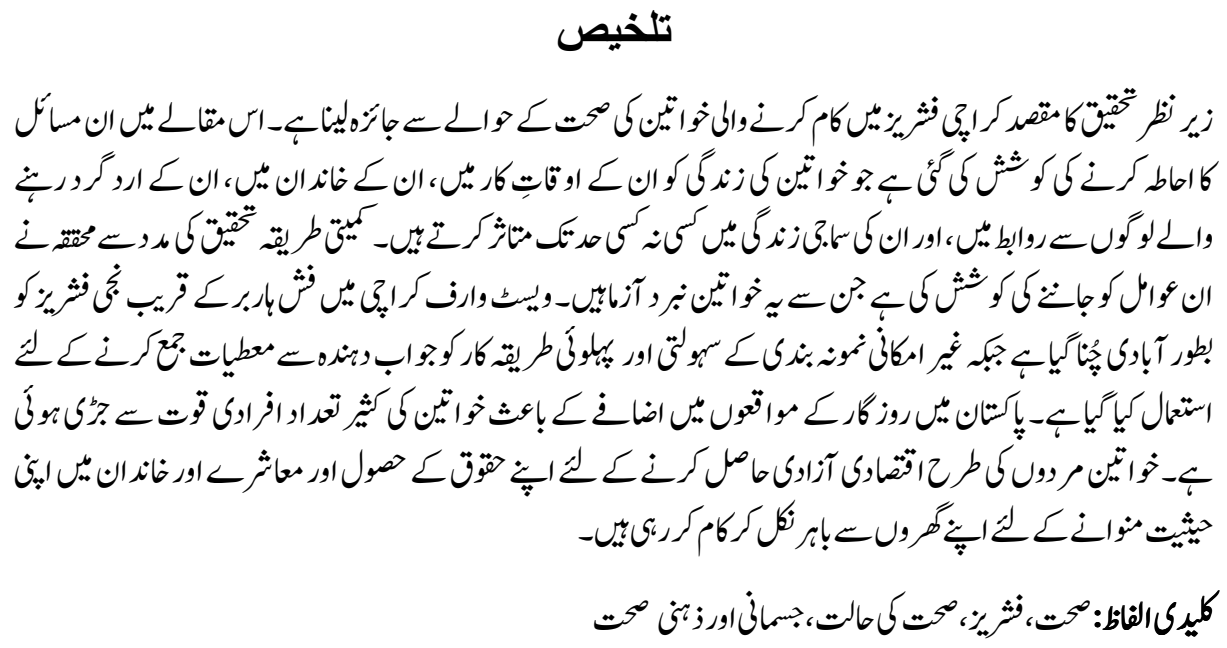




\section{Introduction}

Women suffer all the pain and significant burden of family silently. Depression remains unrevealed as mental health issues in Pakistan and women face this mysterious misery alone (Muray, 1996). Global Burden of Disease study recognized depressive disorder as one of the major cause of worldwide disease burden in 1990, even more common cause than ischemic cardiac arrest, cerebrovascular disease, and tuberculosis (Muray, 1997). The more alarming thing is that depression might become the second major reason of infirmity globally by the year 2020 (Lopez, 1997). Their involvement in various economic sectors as labour force cause them more illness issues due to hazardous working conditions, but they are forced to do work with such worse circumstances as they have to support and feed their family.

As per current studies women labour force in fisheries play a vital role, about 46 percent women are involved in small-scale fisheries related business in nine countries which are major sea food producers. As we see these trends are according to the diminishing fishery stocks and increased demand of sea food globally. Researchers conducted internationally, hardly exposes the level of the women's vital economic participation to men in fisheries especially in the third world countries. Though, it is an established fact that without women's role men might not be able to do fishery business. Men as fishermen are considered full of pride, but women's identity regarding fishery business is hidden and unidentified. Women's role is very supportive in countless ways in assisting men in their work but in return they get very less amount as profit (Worldfish Center, 2011).

Furthermore, women are not considered to be taken onboard in decision making regarding fishery business at any level from household to international level. Unlike farmers and other business communities people involved in fishery business are less educated and have less awareness of health and communication services. In many countries women in fishing areas are marginalized in accessing health and communication services than men. It is a need of the time to implement policies to maintain gender equity and welfare of families involves in small-scale fishing business. It should be dealt now as a serious issue; otherwise gender differences will become more crucial problem due to financial and social costs that will affect fisheries by outcomes of gender issues and climate changes (Worldfish Center, 2010).

\section{Women in Fishing Community}

Like other conventional communities women of fishing community are also over burdened household course and work outside the home. Along with economic activities like sorting fish, packing fish and selling in the market women are also engaged in doing household chores like cleaning, cooking and looking after their children as well (Institute for Community Organization Research, 2011). Women are involved in all types of work related

to fisheries whether sorting, cleaning, packing etc., to have a clear understanding of 
employment in fishing sector it is very important to understand the roots of work in economic, political, socio-cultural and environmental components and all such other factors which design the gender biasness should be taken care of (Long, 2000; Allison and Ellis, 2004).

In the late 1960s and 1970s after the realization that several development plans were not successful because women incorporation was almost nil, women issues were then taken up seriously in order to bring development process back on track. And women inclusion became the essential part of development in all sectors, especially in sectors where smallscale household business are managed. Even after the realization of women's vitality in all economic sectors their social role is undermined, neglected and remain unacknowledged. The previous projects highlighted female's role in the growth perspective (WID), especially in fisheries sector. Because the basic aim of WID theory was to engage women in economic activities and development projects, WID considered it as women's right to step into production sector which they were denied earlier (Ostergaard, 1992).

\section{Health and Hygiene Conditions}

Work environment has direct impact on employee's health. Clean and healthy environment has a positive impact whereas unpleasant environment and poor working conditions leaves bad impact on the health of workers, especially women are affected more. In case if workers are injured during work, they try to hide their wounds and cuts because they think employer may fire them on knowing that they are less productive due to their illness or injury. Women suffer many health issues due to sitting in same position and working for long hours which includes spinal and backache problems. Women of all age groups are engaged in fisheries sector, even teenage girls of age fifteen years are employed. Among these women pregnant women feel very uncomfortable during work due to their health condition.

Women working in fisheries are exposed to extreme temperature, which causes them serious health issues; even separate bathrooms are not available for them. They work on wet floors and wastage of shrimps makes the floor oily, thus making the floor very sticky and greasy for them to work. Emergency medical aid is not provided in these companies. Hygiene conditions are very inappropriate and no working kit is provided like gloves and other tools which can prevent skin and nail damage. Their hands become bruised and injured due to peeling and cleaning fish prawns and other seafood (Sustainable Fishery Policy).

Majority of the women workers are unmarried, they start working at an early age of fifteen years and continue to work around forty years of age. Women in fisheries sector are mostly illiterate or they quit education to support their family. Unlike women of fisheries community, women in other economic sectors (especially women working in export processing zones) have better literacy rate and are more skilled. Their skills, working conditions and salaries are much better than women involved in fishing business. (WHO, World Health Statistics, 2010) 


\section{Specific Health Problems}

Health issues of males and females are different and they have varying proportion regarding health problems. According to the sex-disaggregated data women usually experience joints problems, blood pressure, mental illness and spinal and backache issues. On the other hand males usually suffer from cardiac diseases and lumbar disk disorders (Verbrugge and Patrick, 1995; Guyon, 1996). Working conditions at work place are major contributor to different illness men and women suffer from. If these health issues are not resolved or not taken care of seriously by the authorities, the situation may become more intense for men and women both (Verbrugge and Patrick, 1995).

\section{Review Literature}

In Budapest in February 1982, The World Health Organization Regional Office for Europe arranged a meeting of expert people on 'Women and Occupational Health Risks'. The session concentrated on health issues of women which they experience during work due to the exposure of "toxic substances, physical, biological, psychosocial and ergonomic factors in occupational health". The term working women was not considered on broad spectrum as it is presently; only women who work outside their homes were considered as working women. The health issues which were taken under consideration were mostly related to reproductive health. Later they included that women are more vulnerable than men because of unsuitable equipments and inappropriate working conditions. The understanding was developed that to some extent the data is not appropriate, though women may be less in number than men, but it does not prove that susceptibility is based on gender differences. Another session was held in 1991 by WHO Regional Office for Europe and requested to setup a circumstantial study of women at work in Europe in order to find the core issues which women face during work (Maw, 1991).

On the basis of facts and figures the report analyzed quantity of women working in European industries and professions in which they are in large number, along with that it also evaluated the future working scenario and changes in employment trends. Like previous session only work outside home was taken under consideration. Paid and unpaid work and formal and informal work carried out inside home were not discussed in detail, and the report was not much useful because it was not implemented, and remained in document form only. But in 1994 in collaboration with occupational health centers World Health Organization organized another session on the same topic with a notion of occupational health for all. This proposal was adopted officially in $49^{\text {th }}$ World Health Assembly on $25^{\text {th }}$ May 1996 . The document was definitely unquestionable in catering the urgency to improve the occupational health, safety of workers and to enhance work-related health services, but it had limitations as it does not focus the requirements and issues of women's occupational health. 
In current decade clear acceptance of human rights in the sector as per international rules were also analyzed particularly in fisheries sector. Since 2007 in collaboration with public sector the UN Food and Agriculture Organization (FAO) has outlined to advice and establish policy in terms of human rights regarding small-scale fishing business (FAO, 2007; FAO, 2009; FAO, 2012). FAO committee on fisheries planned to intend to its 192 members to ratify the new set of governance instrument in June 1994, which has all guidelines regarding small-scale fishery business FAO (2013), by virtue of which human rights tools would be channelized.

In Fishery business almost forty seven percent women are involved, , mainly doing work including sorting, cleaning and packing etc., it is not an easy task because it involves efforts to make sure that about one billion consumers eat fish with all its actual nutrient value (World Bank, 2010). According to few researches it is quite evident that women's contribution in fisheries as labour force is almost equal to men engaged in all sort of postharvest activities. Various facts and figures shows that only in Europe, female fish workers are sixty percent in proportion. Women usually do not work on fish vessels still a large number of women's workforce is hired in fish processing (FAO and WFC, 2010).

Like some other economic sectors fishing is also considered as men's sector, catering their nature of exploring and taking risks. But women are engaged in both before and after catch activities, all major fish producing nations have almost forty six percent women working as workforce in fishing industry (FAO, World Fish Centre and World Bank, 2008). If women worker's quantity is measured in harvesting and aquaculture both, their incorporation in this sector may exceed than the estimated figures. Such facts and figures fail to reveal actual number of women's involvement in fishing sector and in income generation.

Another factor highlighted by FAO is that small-scale fishermen are relegated in all aspects of life that is financial, social and political as well. Even local people and deprived castes face many hurdles in decision making regarding development at wider level (Osaghae, 1995; Doyen, 2002; Pattanaik, 2007; Jana, 2007). The basic reasons behind inequalities and imbalanced power relation is a result of government's failure in implementing policies to maintain human rights and to provide benefits to all regardless of class caste and race. Women are now involved in economic activities outside their homes and are facing health issues also. Their quantity has increased gradually in all economic sectors even in industrial sector. The newly emerging Asian industrialized countries shows the trend that feminization of labour has increased very quickly. The facts shows that since 1960s women workforce has increased very fast as compared to males, though their jobs are not as high profiled as men, their wages and skills are lower than men. Women workers are working in economic activities which are mainly based on exports of electronic items and textiles, which are key export products (Lin, 1993). 
The existing indicators cannot encompass the problems and issues women face during work, these indicators fail to examine the reason of accidents which occur during work. Men get more compensation for injuries during work unlike women (Robinson, 1989; Wagener and Winn, 1991; Lauring, 1991; Pines et al., 1992). It is noticed that since men and women have different types of jobs, within the companies sometimes women suffer more accidents than men or vice versa, but women catch other health issues like work borne diseases more than men. Their issues are overlooked as for many work borne diseases are not acknowledged. An accident which involves broken leg or machine borne injuries are considered as workplace problems, but an allergic reaction or swelling that produces more gradually is not easily associated with the job (Kraut, 1994). On technical grounds women's workplace injuries are reduced synthetically, considering that working hours for women are less than men, and rate of accidents is also calculated on the grounds of per worker rather than work per hour. These are the exploiting techniques and manipulation of facts (Messing et al., 1994).

\section{Methodology}

This study focuses on the significant roles played by the women in all aspects of fisheries both in the small-scale and in the commercial sector, as their production and reproduction role is neglected and remain unrecognized. Therefore, the study focused on collecting data regarding their health issues by using quantitative research method and descriptive survey method from private fisheries near Fish Harbour, West Wharf, Karachi. Convenience and purposive sampling techniques of non-probability sampling method are used in order to collect the data by hundred respondents from various private fishing companies at Karachi fisheries. Descriptive method is used to get the insight and exact situation about the health issues of women working at fisheries, to highlight the affects of work on their lives and its impact on their health.

\section{Results}

Table: 1

Distribution of the respondents according to their age groups

\begin{tabular}{|l|c|c|}
\hline Age Groups in Years & Frequency & Percentage \\
\hline Less then and equal to 15 years & 13 & $13 \%$ \\
\hline $16-20$ years & 43 & $43 \%$ \\
\hline $21-25$ years & 22 & $22 \%$ \\
\hline $26-30$ years & 9 & $9 \%$ \\
\hline More than 30 years & 13 & $13 \%$ \\
\hline Total & $\mathbf{1 0 0}$ & $\mathbf{1 0 0 \%}$ \\
\hline
\end{tabular}

Data shows that $43 \%$ of respondents belong to the age group of $16-20$ years, $22 \%$ belong to the $21-25$ years and $13 \%$ from less then and equal to 15 and More than 30 years. Showing high percentage of teenage female workers means a clear violation of labour laws. 
Table: 2

Distribution of the respondents according to their monthly income

\begin{tabular}{|l|c|c|}
\hline Monthly Income of the Respondent & Frequency & Percentage \\
\hline $5001-6000$ & 28 & $28 \%$ \\
\hline $6001-7000$ & 10 & $10 \%$ \\
\hline $7001-8000$ & 4 & $4 \%$ \\
\hline $8001-10000$ & 52 & $52 \%$ \\
\hline More than 10,000 & 6 & $6 \%$ \\
\hline Total & $\mathbf{1 0 0}$ & $\mathbf{1 0 0 \%}$ \\
\hline
\end{tabular}

The above data shows the monthly income of the respondents that $52 \%$ falls in the category of $8001-10,000,28 \%$ in the category of 5001-6000, $10 \%$ falls in the category of 6001-7000, while $6 \%$ were earning more than 10,000 per month and $4 \%$ were earning income just to meet their daily bread and butter needs.

Table: 3

Distribution of the respondents according to the type of work

\begin{tabular}{|l|c|c|}
\hline Type of Work & Frequency & Percentage \\
\hline Grading & 39 & $39 \%$ \\
\hline Packing & 28 & $28 \%$ \\
\hline Grading and packing & 32 & $32 \%$ \\
\hline Supervisor & 1 & $1 \%$ \\
\hline Total & $\mathbf{1 0 0}$ & $\mathbf{1 0 0 \%}$ \\
\hline
\end{tabular}

Data shows that $39 \%$ of the respondents were engaged in grading, $32 \%$ were involved in both grading and packing, where as $28 \%$ does packing only and $1 \%$ were those who were supervising the workers. These percentages indicating distribution of respondent's job; it also shows different typologies of work they were involved in.

\section{Table 4}

Distribution of the respondents according to their working hours

\begin{tabular}{|l|c|c|}
\hline Working Hours & Frequency & Percentage \\
\hline 8 hours & 5 & $5 \%$ \\
\hline 10 hours & 95 & $95 \%$ \\
\hline Total & $\mathbf{1 0 0}$ & $\mathbf{1 0 0 \%}$ \\
\hline
\end{tabular}

Data shows that $95 \%$ of the respondents worked for 10 hours daily and $5 \%$ for 8 hours to earn their bread and butter both for their family members and for themselves. 
Table: 5

Distribution of the respondents according to the effect of the job on their health due to constant sitting

\begin{tabular}{|l|c|c|}
\hline $\begin{array}{l}\text { Effect on Health Due to Constant Sitting } \\
\text { During Work }\end{array}$ & Frequency & Percentage \\
\hline Backache & 17 & $17 \%$ \\
\hline Pain in Legs & 5 & $5 \%$ \\
\hline Joints Pain & 4 & $4 \%$ \\
\hline Backache and Pain in Legs & 61 & $61 \%$ \\
\hline Backache, Pain in Legs and Joint Pain & 12 & $5 \%$ \\
\hline Flu & 1 & $1 \%$ \\
\hline Total & $\mathbf{1 0 0}$ & $\mathbf{1 0 0 \%}$ \\
\hline
\end{tabular}

Data clearly indicates that all of the respondents said that work affects their health and out of those $61 \%$ of the respondents complaining that they had backache and pain in legs due to their work, $17 \%$ suffered only backache where as $12 \%$ said that they had multiple problems like backache, pain in legs and joint pain, 5\% said that they had only pain in legs due to long working hours and constant sitting, while $4 \%$ had only joint pains, and $1 \%$ reported rapid flu problem.

Table: 6

Distribution of the respondents according to physical and mental problem faced by the respondents due to work

\begin{tabular}{|l|c|c|}
\hline Physical and Mental Problem & Frequency & Percentage \\
\hline Yes & 76 & $76 \%$ \\
\hline No & 24 & $24 \%$ \\
\hline Total & $\mathbf{1 0 0}$ & $\mathbf{1 0 0 \%}$ \\
\hline
\end{tabular}

Data shows that $76 \%$ of the respondents said that their mental and physical health also affected due to work they were doing and $24 \%$ said that they had no problem and comfortable with their work.

Table: 6.1

Distributions of the respondents according to, if yes then any what are the effects

\begin{tabular}{|l|c|c|}
\hline What are the Effects & Frequency & Percentage \\
\hline Muscle Cramps & 3 & $3.90 \%$ \\
\hline Mental Tension & 1 & $1.30 \%$ \\
\hline Stress / Tiredness & 50 & $66 \%$ \\
\hline Depression & 1 & $1.30 \%$ \\
\hline Muscle Cramps, Mental Tension, Stress and depression & 4 & $5.26 \%$ \\
\hline Muscle Cramp and Stress & 14 & $18.40 \%$ \\
\hline Stress and Depression & 3 & $3.90 \%$ \\
\hline Total & $\mathbf{7 6}$ & $\mathbf{1 0 0 \%}$ \\
\hline
\end{tabular}


While asking about how work effects on their health $66 \%$ of the respondents complaining stress or tiredness feeling, $18.40 \%$ were effected with muscle cramps and stress whereas $5.26 \%$ were said that they had multiple issues like muscle cramps, mental tension, stress and depression, $3.90 \%$ each said that they were suffering from muscle cramps and stress \& depression due to strenuous work, and $1.30 \%$ each reported mental tension and depression.

Table: 7

Distribution of the respondents according to the damage to hands and nails due to work

\begin{tabular}{|l|c|c|}
\hline $\begin{array}{l}\text { Hands and Nails Damaged Due to } \\
\text { Work }\end{array}$ & Frequency & Percentage \\
\hline Yes & 6 & $6 \%$ \\
\hline No & 94 & $94 \%$ \\
\hline Total & $\mathbf{1 0 0}$ & $\mathbf{1 0 0 \%}$ \\
\hline
\end{tabular}

Data has shown that $94 \%$ of the respondents do not get hurt by any means due to work where as $6 \%$ were complaining about damaged hands and nails.

Table: 8

Distribution of the respondents according to the effects on eyesight

\begin{tabular}{|l|c|c|}
\hline Is the Eyesight Effected & Frequency & Percentage \\
\hline Yes & 6 & $6 \%$ \\
\hline No & 94 & $94 \%$ \\
\hline Total & $\mathbf{1 0 0}$ & $\mathbf{1 0 0 \%}$ \\
\hline
\end{tabular}

Data shows that the eyesight of $94 \%$ of the respondents was not affected where as $6 \%$ said that they developed eyesight problem due to this work.

Table: 9

Distribution of the respondents according to the miscarriages due to job

\begin{tabular}{|l|c|c|}
\hline Any Miscarriage Due to Job & Frequency & Percentage \\
\hline No & 100 & $100 \%$ \\
\hline Total & $\mathbf{1 0 0}$ & $\mathbf{1 0 0 \%}$ \\
\hline
\end{tabular}

Data reflects that none of the respondents out of $100 \%$ faced any miscarriage due to this job. Major reason was that majority of the respondents were unmarried and those who were married never face this issue. 


\section{Discussions}

This paper analyzes the health status of women workers at fisheries and the motives which compel them to fulfil the financial needs of their family; as a result their health is affected due to triple burden. Work place environment plays a very important role in determining the health conditions of workers. Work place having proper light arrangement, and clean airy surrounding lays good impact on the health of workers, whereas lack of all such arrangements affects worker's health badly. Employer does not provide working kit to their employees and they are forced to work under such hazardous conditions, due to which they even hide their cuts and wounds because they fear of losing their job. They even suffer backache issues due to working for longer hours sitting in the same position. The labour force constitutes of women of all ages, but most of them are below twenty. Such poor working conditions might be lethal for pregnant women. According to the findings of study $43 \%$ of respondents belong to the age group of $16-20$ years, $22 \%$ belong to the $21-25$ years and $13 \%$ each from less then and equal to 15 years and more than 30 years of age bracket. Showing high percentage of teenage female workers means a clear violation of labour laws. The monthly income of these respondents shows different trends as per their work that is 52\% falls in the category of 8001 $10,000,28 \%$ in the category of $5001-6000,10 \%$ falls in the category of $6001-7000$, while $6 \%$ were earning more than 10,000 per month and $4 \%$ were earning income just to meet their daily bread and butter needs. The typology of work shows the division of labour in these factories such as $39 \%$ of the respondents were engaged in grading, 32\% were involved in both grading and packing, where as $28 \%$ does packing only and $1 \%$ were those who were supervising the workers. These percentages indicating distribution of respondent's job; it also shows different typologies of work they were involved in.

Long working hours affects women's health badly according to the results $95 \%$ of the respondents worked for 10 hours daily and $5 \%$ for 8 hours to earn their bread and butter both for their family members and for themselves. Data clearly indicates that all of the respondents said that work affects their health and out of those $61 \%$ of the respondents complaining that they had backache and pain in legs due to their work, $17 \%$ suffered only backache where as $12 \%$ said that they had multiple problems like backache, pain in legs and joint pain, 5\% said that they had only pain in legs due to long working hours and constant sitting, while $4 \%$ had only joint pains, and $1 \%$ reported rapid flu problem. Out of hundred respondents $76 \%$ of the respondents said that their mental and physical health is also affected due to the work they were doing, and $24 \%$ said that they had no problem and comfortable with their work. While asking about how work effects on their health $66 \%$ of the respondents complaining stress or tiredness feeling, $18.40 \%$ were effected with muscle cramps and stress whereas $5.26 \%$ were said that they had multiple issues like muscle cramps, mental tension, stress and depression, $3.90 \%$ each said that they were suffering from muscle cramps and stress \& depression due to strenuous work, and $1.30 \%$ each reported mental tension and depression. As per data $94 \%$ of 
the respondents do not get hurt by any means due to work where as $6 \%$ were complaining about damaged hands and nails. The eyesight of $94 \%$ of the respondents was not affected where as $6 \%$ said that they developed eyesight problem due to this work. Results also reflect that none of the respondents out of $100 \%$ faced any miscarriage due to this job. Major reason was that majority of the respondents were unmarried and those who were married never face this issue.

Data also indicates that during work $35 \%$ of the respondents were facilitated by medicine only, $26 \%$ of the respondents said workers avail both facilities and $9 \%$ said they are taken to hospital in any emergency only. All of the $100 \%$ respondents claims that they don't get any benefit or facility during maternity leave.

\section{Conclusions}

The study has been carried out to identify and evaluate the issues faced by the working women in fisheries throughout work, within the families, and while dealing with people in their community. Low status of women in fishing sector is very noticeable because in policy documents government has not even mentioned a single clause regarding women working in fishery sector. Women's contribution in fishing sector is remarkable without any doubt but unfortunately their efforts, hard work, triple burden and unconditional support to their family remains unrecognized. This study has also analyzed the health problems which directly affect women working in this specific field. The economic activities of this sector can be enhanced to its highest limits only by boosting health status and social issues of women because they are the backbone of national economy. By making proper gender based policies and efforts to boost up fishery sector along with realization of women's worth and importance in fishery, government can get maximum benefit out of this sector only. As per findings of this study by interviewing hundred respondents it was evident that women's involvement in all areas of fishing industry is a key of making out the best from this industry by regularizing all the processes and procedures. Women being major contributor are eligible to get health facilities and medical benefits along with men.

\section{References}

Allison, E.H. and Seeley, J.A. (2004). HIV and AIDS among Usher Folk: a Threat to 'Responsible Fisheries'? Fish and Fisheries, vol. 5, pp.215-234.

Doyen, S. (2002). The Structural Marginalization Of Artisanal Fishing Communities: The Case Of La Boquita, Anthropological, vol.44:1, pp. 83-98. 
FAO. (2007). Food and Agriculture Organization of the United Nation, Report of the Twenty-seventh Session of the Committee on Fisheries, Rome, FAO.

FAO. (2009). Food and Agriculture Organization of the United Nations, Securing Sustainable Small-scale Fisheries: Bringing Together Responsible Fisheries and Social Development, Rome, Committee on fisheries, Twenty-eighth session, FAO.

FAO. (2012). Food and Agriculture Organization of the United Nations: Voluntary Guidelines on the Responsible Governance of Tenure of Land, Fisheries and Forests in the Context of National Food Security, Rome, FAO.

FAO. (2013). Food and Agriculture Organization of the United Nations, Resumed Session of The Technical Consultation on International Guidelines on Securing Sustainable Small-Scale Fisheries, Rome, FAO.

FAO. ,World Fish Center., and World Bank. (2008). Small-Scale Capture Fisheries - A Global Overview With Emphasis On Developing Countries: A Preliminary Report Of The Big Numbers Project, Rome \& Penang, FAO and World Fish Center, p.62.

Food and Agriculture Organization and World Fish Center. (2010). Small-Scale Capture Fisheries -A Global Overview with Emphasis on Developing Countries, A Preliminary Report of The Big Numbers Project.

Institute for Community Organization Research. (2011). Nutritional and Health Status Of Fishing Communities in the Uttan-Gorai area with Special Emphasis on Women, Mumbai, India, Institute for Community Organization Research, p.15.

Jana, S. (2007). Working Towards Environmental Justice: An Indigenous Fishing Minority's Movement in Chitwan National Park, Kathmandu, Nepal, International Center for Integrated Mountain Development.

Kraut, A. (1994). Estimates Of The Extent Of Morbidity And Mortality Due To Occupational Diseases In Canada, Am. J. Ind. Med, vol.25, pp.267-278.

Lauring, G. (1991). Feminisation De La Main D'oeuvre: Impact Sur La Sante Et La Securite Du Travail Commission De La Sante Et De La Securite Du Quebec, Montreal, Quebec.

Lin, Lean Lim (1993). The Feminisation Of Labour In The Asian-Pacific Rim Countries: From Contributing To Economic Dynamism To Bearing The Brunt Of Structural Adjustments, In Human Resources In Development Along The Asian-Pacific Rim, 
(eds.) N. Ogawa, G. Jones \& J.G. Williamson, Singapore, Oxford University Press, pp.176-209.

Long, N. (2000). Exploring local/global transformations: a view from anthropology, In: Anthropology, Development and Modernities (eds. A. Arce and N. Long), London, Koutledge, pp.184-201.

Maw, J. (1991). Situational Analysis of Women at Work in Europe: Research Project for the World Health Organization Occupational Health, Unpublished ms.

Messing, K., Dumais, L., Courvillle, J., Seifert, A. M. and Boucher, M. (1994). Evaluation Of Exposure Data From Men And Women With The Same Job Title, Journal of Occupational Medicine, vol.36:8, pp.913-917.

Muray, C.J.L. and Lopez, A.D. (1996). Global Burden of disease, Cambridge, Mass: Harvard University Press, p.84.

Muray, C.J.L. and Lopez, A.D. (1997). Alternative projections of mortality and disability by cause 1990-2020: Global Burden of Disease study, Lancet, vol.349, pp.14981504.

Muray, C.J.L. and Lopez, A.D. (1997). Global mortality, disability and the contribution risk factors: global burden of disease study, Lancet, vol.349, pp.1436-1442.

Osaghae, E. (1995). The Ogoni Uprising: Oil Politics, Minority Agitation And The Future Of The Nigerian State, African Aff., vol. 94:376, pp.325-344.

Ostergaard, L. (1992). Gender. In Lise Ostergaard (ed.), Gender and Development: A Practical Guide, London and New York, Routledge, pp.220.

Pattanaik, S. (2007). Conservation Of Environment And Protection Of Marginalized Fishing Communities Of Lake Chilika In Orissa, India, J. Human Ecol., vol.22:4, pp.291-302.

Pines, A., Lemesch, C. and Grafstein, O. (1992). Regression Analysis Of Time Trends In Occupational Accidents (Israel, 1970-1980), Safety Science, vol.15, pp.77-95.

Robinson, J.C. (1989). Trends In Racial Inequality And Exposure To Work-Related Hazards, 1968-1986, AAOHN Journal, vol.37, pp.6-63.

Sustainable Fishery Policy, http://www.cpcs.org.pk/docs/presentations, retrieved on June $18,2015$. 
Verbrugge, L.M. and Patrick, D.L. (1995). Seven chronic conditions: their impact on US adults' activity levels and use of medical services, American Journal of Public Health, vol.8:2, pp.173- 182.

Wagener, D.K. and Winn, D.W. (1991). Injuries In Working Populations: Black-White Differences, Am J Publ. Health, vol.81, pp.1408-1414.

World Bank., Food and Agriculture Organization. and World Fish Center. (2010). The Hidden Harvests -The Global Contribution Of Capture Fisheries, Conference Edition, Washington DC.

World Health Statistics. (2010). Health and Hygiene Conditions, Available at, http://herproject.org/downloads/country-resources/her_health_needs_bangladesh, pdf.

World Fish Center. (2010). Gender and fisheries: Do women support, complement or subsidize men's small-scale fishing activities?, Issue brief 2108, Penang, Malaysia, World Fish Center, p.8.

World Fish Center. (2011). Gender and aquaculture: Sharing the benefits equitably (Issues Brief | 2011-32), World Fish Center.

Seema Manzoor is Lecturer in the Centre of Excellence for Women's Studies, University of Karachi.

Dr. Asma Manzoor is Assistant Professor in the Centre of Excellence for Women's Studies, University of Karachi.

Dua-e-Rehma is Lecturer in the Centre of Excellence for Women's Studies, University of Karachi.

Dr. Samina Saeed is Associate Professor and Chairperson in the Department of Political Science, University of Karachi. 